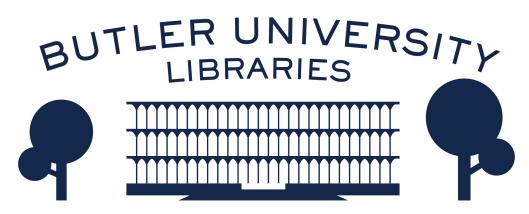

Journal of Hindu-Christian Studies

Volume 12

Article 10

January 1999

\title{
Viewpoint: Conversions in India: An Interim Report on the Discussion on the Hindu-Christian Studies List January-March 1999
}

Francis X. Clooney

Follow this and additional works at: https://digitalcommons.butler.edu/jhcs

Part of the Religion Commons

\section{Recommended Citation}

Clooney, Francis X. (1999) "Viewpoint: Conversions in India: An Interim Report on the Discussion on the Hindu-Christian Studies List January-March 1999," Journal of Hindu-Christian Studies: Vol. 12, Article 10. Available at: https://doi.org/10.7825/2164-6279.1208

The Journal of Hindu-Christian Studies is a publication of the Society for Hindu-Christian Studies. The digital version is made available by Digital Commons @ Butler University. For questions about the Journal or the Society, please contact cbauman@butler.edu. For more information about Digital Commons @ Butler University, please contact digitalscholarship@butler.edu. 


\title{
VIEWPOINT
}

\section{Conversions in India: An Interim Report on the Discussion on the Hindu-Christian Studies List January-March 1999}

\author{
Francis X. Clooney, SJ \\ Boston College
}

THE HINDU-CHRISTIAN Studies List (HCS-L) came alive in the middle of January when the question was asked on the List how scholars engaged in HinduChristian studies should respond to the flareup of violence in India involving Hindus and Christians and the issues connected with conversion. Should people ever convert from one religion to another? Would people ever convert if it were not for force, fear, material inducements? Is a truly spiritual conversion so rare an occurrence that it proves nothing about the phenomenon of missionary programs to change people's religions? Is the condemnation of acts of violence against Christians an act of selective memory which overlooks a longer history of Western colonialist and missionary violence against Hindu culture and religion? Is the only future path the abandonment by believers of all efforts to convert others? What should Indians do politically, socially, religiously - in the face of religious violence? And what do scholars involved in Hindu and Christian studies have to do with any of this?

The conversation and the questions involved certainly caught the attention of the Society's members. Two months later, as of this writing in mid-March 1999, there have been well over 150 contributions to this continuing conversation. Typical of the make-up of the Society itself, most of the contributors - henceforth "participants" are Americans, or based in America, and most are engaged in the scholarly study of Indian religious traditions, particularly the Hindu. (There was some on-line discussion at one point about broadening the discussion by drawing in new participants, but not too much progress was made in this regard.) While talking about matters related to religion and religious conflict in India, most of us also had an eye on the North American scene, where the realities of Christian life and Hindu life have been working out very differently, in a very different cultural and religious setting. What is quite prominent in the minds of many Indians - issues surrounding missionaries and conversions seems for most participants in this conversation to be only a minor part of everyday life as lived in the West, even among devout Christians. The tensions and unhappy memories have thus far not poisoned Hindu-Christian relations in the West.

Readers who have participated in this sort of on-line discussion will know how lively they can be, but also how they become easily entangled with all the other business we now carry on by e-mail, and how easy it is for prolonged discussions to become unwieldy as short, middle-length, 
and some very long messages compete with each other for readers' attention, as sideissues spring up and blossom, and as intense conversations among two or three participants tend to occupy as much space as comments addressed to all. By nature, this kind of on-line discussion proceeds without the benefit of a chair; it is as if everyone has his or her own microphone and can speak at will, moving ahead or looping back in the conversation as seems desirable at the moment. No one has the power or responsibility to guide and refocus or monitor the conversation. But despite the drawbacks of trying to carry on so large a conversation by e-mail, it has been very successful and important for those participating in it and, I suspect, for a wider audience as well.

The following paragraphs sketch some main features of the conversation as relevant to the work of scholars; readers are of course invited to view the archives of the whole discussion at our website (http://www.acusd. edu/theo/hcs-1). Some contributors made very helpful bibliographical references, and some even cited, briefly or at length, documents relevant to the history of conversions, the Indian legal system, and related studies of violence, human rights, etc. Much of this information provides a rich store of materials for further research, certainly beyond what we were able to explore fully during these two months of discussion, and cannot be taken into account here. I have made this summary from my own perspective as one participant, with the understanding that next year's Bulletin will provide space for alternate readings of the conversation and perhaps longer assessments of the debate over conversions itself. (Such further contributions should be addressed directly to the Editor of the Bulletin.)

It was no surprise, thankfully, that no one on the List argued in favour of violence, religious or other, and no one thought it defensible to compel people to change their religions. Particularly early on, though to some extent throughout, some of the discussion was anecdotal, aimed at adducing good and bad examples of Hindu-Christian interaction. Instances of violence against Christians were countered with instances of forced conversions of Hindus; both were countered with instances of happier moments where Hindus and Christians lived together in peace, where missionaries have not tried to compel conversions, and where majorities have not persecuted minorities. This trade of anecdotes was in my judgment inconclusive, since our dispersion across the globe and engagement in different kinds of scholarship made it impossible for us to study any particular anecdote in detail and figure out what was really going on. We were not in a position on the List to step back and engage in a sociological and statistical analysis of the anecdotes, in search of patterns. There was some progress, though not complete consensus, toward a wider judgment that violence and compulsion are atypical. Since the discussion was intended to be scholarly, we were not in a position to set policies or influence the public agenda. Judgments about the real significance of specific events had to be tentative and open to revision. The primary question throughout remained how scholars could make a useful contribution in the contemporary situation.

Most interesting were some of the necessary explorations of terminology and a related set of distinctions introduced in the course of the discussion. Much energy was given to a useful argument over whether conversion from one religion to another can be a spiritually valuable event; most seemed to agree that it could be (just as remaining in one's own tradition may more often be spiritually wise), although some argued that conversion more often is not a spiritual event. At one point we sorted out a series of terms, including "conversion", "mission", "evangelization", "proselytization", etc., and we all at least agreed that one has to define one's terms before evaluating behaviour. A related but even more vexed topic was whether group conversions do or ever have made any sense. It . was pointed out how earlier on in history (in both India and the West) it was customary for entire families, tribes, even kingdoms, to change religions 
according to a decision made by a patriarch or ruler. Group conversions might make sense in certain situations where family and community identity take precedence over the rights and choices of individuals. But no one defended group conversions today, since any such group would still have to be made up of individuals, each making a free choice to convert.

Discussing whether a Hindu could or should become a Christian (or vice versa) eventually entailed an examination of what it means to be a Hindu or a Christian, and what is referred to by "Hinduism" and "Christianity". Are there perennial decisive truths and values that fix each tradition or is it right to adduce any number of differing voices which alter and redefine the meanings of the terms? As might be expected from wider patterns in academe which are operative even quite apart from this particular discussion, modern scholars (particularly in the West, and including scholars with personal religious commitments) tend to be rather comfortable with much of the demythologization, historicization, and complexification of traditions. In the West, even faithful theologians are now accustomed to taking apart Biblical narratives, problematizing Christian communities' stories about themselves, and resisting the dominance of majority accounts. Such scholars are accustomed to contributing to discussions such as this one by changing the question about conversions into a series of studies about communal identities, historical processes of adaptation and conflict, and theoretical frameworks in which to rethink both the idea of conversion and the alternatives to it. Indeed, one contribution of scholars - who can help but of course not monopolize reflection on contemporary issues - is to resist simplifications and point to the complexities which make the simple deification or demonization of traditions and their representatives implausible; but this same scholarship may impact on different believing communities in different ways, and in any case what works in the West may not work so well in India.
We also looked at the issue of conversion from the other side. That is, if conversion is not to be ruled out entirely, neither can one rule out the idea that people in a tradition - we were thinking mainly, though not only, of Christians - may feel that they have a calling to convert others, or at least to witness publicly to their beliefs. However this effort is described - mission work, proselytization, evangelization, etc. most of us seemed willing to show, respect for the idea of "witness", whereby one simply lives and speaks of one's beliefs, making them available for others to consider, without strategizing about how to bring about acceptance. More problematic, of course, is witness encumbered by unexamined ideology - e.g. an a priori, unchallenged evangelical depiction of the woeful condition of the unconverted, their presumed misery, their possible or likely damnation. At one point we considered the specific example of an American evangelical missionary magazine which was deeply imbued with dramatic language of good spirits and demons, light and dark, salvation and damnation, the true God and false gods; it described north Indian culture almost exclusively through that Biblical lens, without much attention at all to other ways of viewing the culture, or even to facts at all. But here too we did not reach any normative conclusions about how people in one tradition are supposed to think about people in other traditions.

As the discussion progressed, it was enriched by considerable attention to history, and this of course is one of the contributions that scholars can justly make. The contemporary interaction among Hindus and Christians in India has to be located in the perspective of both traditions and their more particular subdivisions, their longer term habits of self-identification and treatment of outsiders. Some pointed also to the history of missionary endeavours in the West itself (even today), the nature of interreligious fighting in European countries, Buddhist evangelism throughout Asia and then also in the West, and so to the (real though less widespread) instances of 
"evangelization" by Hindus seeking the conversion or reconversion of Buddhists, Jains, and even other Hindus who live according to "deficient" principles. We alluded at various points to studies of mission history and the worldviews of missionaries but could not, in this discussion, give that history any detailed attention. Most in the conversation recognized that our contemporary sensitivities differ from those of past generations; it is fruitless to condemn by today's standards actions undertaken long ago, just as it is mistaken to approve the modern counterparts of such actions merely by pointing out that they made sense in the past. Here too, participants tried to assess what was historically typical and atypical, since no one thought that a single example could serve to prove a point even regarding matters long past.

But in light of the deeply felt convictions and hints of anger expressed by some participants, it is very clear that Hindu-Christian relations today are still profoundly affected by a colonial past in which religious values were mixed with political and economic power, to the severe disadvantage of Indian religious traditions and also by the continuing zeal, in some circles, of Christians seeking to convert others. Participants were made aware of how bitter the history of Christian interventions in India is and has been for many Hindus, even among those who recognize the many good things said and done by many good missionaries over the generations. Too often missionaries lacked respect for Hindu beliefs and practices and belittled sacred truths and realities they did not understand and had no right to dismiss so contemptuously. Several participants, while deploring the present violence against Christians, concluded that this situation only underlined the crying need for a profound reexamination and reconfiguration of the whole issue of missions and evangelization within Christianity.

In turn, at several points the conversation opened up into reflection on the identities of the participants themselves.
Who speaks for a tradition, and who is able to explain it? What happens when a scholar who is not a member of a tradition simply disagrees with the presentation of a tradition's meaning by a member of that tradition? As mentioned above, most participants are of Western background, and most of those, I think, grew up in some kind of Christian context; a much smaller but very valuable number of participants were Indian Christians, and likewise a small number of (much appreciated) participants were Hindus. Almost all involved are scholars, and most of these are dedicated to the study of some aspect of Hinduism, either by itself or in a comparative perspective. Scholars of course recognize the limits of what can be learned by study and are (usually) willing to defer to members of a tradition on the subtler aspects of identity, belief, practice. But as in other fields of endeavour, scholars will still look deeply into source materials and see things with a certain objectivity that is more difficult for people within a tradition. One way the tension between the viewpoints of scholars and believers surfaced in our discussions was the presumption of most participants that both the Hindu and Christian traditions are complicated realities that can never be reduced to a single view or single way of acting, and that views on conversions could not be reduced to "the Hindu view" or "the Christian view", etc. Clearly this complicates calls to action according to the Christian view or the Hindu view.

Occasionally someone would remind us that although we were talking a lot about low-caste, untouchable, and tribal communities where external initiatives aimed at conversion are more common, those people themselves were not present in the discussion, and yet they surely have particular perspectives and interests which, if listened to, would give the discussion of the pros and cons of conversion a sharper and more urgent edge.

As anyone who consults the archival record of this on-line conversation will notice, it is not easy to draw conclusions from so large a discussion; in fact we did not 
try to come to a consensus beyond the rather basic (and not specifically scholarly) judgments mentioned earlier, that compulsion and violence have no place in the contemporary encounter of people of different religious traditions, that evangelical fervour is no excuse for ignorance of or contempt for other people's religions, and that evangelism, probably a constituent element of Christian identity, is unlikely to cease. As indicated in the preceding paragraphs though, the patterns are clear enough to suggest that a scholar familiar with both the Christian and Hindu traditions can make a contribution in the current situation by clarifying what is at stake, by seeing the present in light of the past, and by showing how both the Hindu and Christian traditions are richer and more complex than many people, particularly in heated arguments and moments of controversy, admit them to be. Such conclusions are of course only preliminary steps, and it is for the participants as individual scholars to develop in their publications points they or others have made on-line, and to draw further conclusions about conversion as a theological concept to be rethought in the context of Hindu-Christian studies. As mentioned above, the Bulletin will provide space in next year's issue for further reflections on conversions and on the on-line discussion and, I conjecture, the archive on this subject will continue to grow in the meantime. 